\title{
Research Article \\ Open Access \\ Influence of Genotype and Harvest Season on the Phytochemical Composition of Araçá (Psidium Cattleianum Sabine) Fruit
}

\author{
Andrea Miranda Teixeira ${ }^{1}$, Fabio Clasen Chaves $^{2}$, Rodrigo Cezar Franzon ${ }^{3}$, Cesar Valmor Rombaldi ${ }^{2 *}$ \\ ${ }^{1}$ Uergs, Unidade Cachoeira do Sul, CEP 96508-010, Cachoeira do Sul, RS, Brazil \\ ${ }^{2}$ UFPel/FAEM, Department of Agroindustrial Science and Technology, C.P. 354, CEP 90010-900, Pelotas, RS, Brazil \\ ${ }^{3}$ Embrapa Clima Temperado, BR 392, Km 78, C.P. 403, 96010-971, Pelotas, RS, Brazil
}

"Corresponding author: Cesar Valmor Rombaldi, UFPel/FAEM, Department of Agroindustrial Science and Technology, C.P. 354, CEP 90010-900, Pelotas, RS, Brazil, Tel: +55 53 32757284; E-mail: cesarvrf@ufpel.edu.br

\begin{abstract}
L-ascorbic acid, total anthocyanin, total carotenoid, total tannin, total and individual phenolic compounds content, antioxidant potential, and antiproliferative activity against tumoral cells of extracts from six Araçá genotypes (AR9, AR19, AR29, AR27, AR46 and AR72) from six consecutive harvest seasons (2008, 2009, 2010, 2011, 2012, and 2013) were evaluated. Results showed that in general variations in phytochemical content were greater among genotypes than among harvests. Whereas red genotypes (AR9, AR19, and AR29) had higher anthocyanin and total phenolic content, yellow genotypes (AR46, and AR72) had higher L-ascorbic acid content. (-)-Epicatechin was the most abundant phenolic compound found in the fruits, followed by gallic acid, in all genotypes. Only soluble solids, $\mathrm{pH}$, and total tannin content were not affected by harvest year. Regarding the antioxidant capacity against $S$. cereviseae XV 185-14C cells, all extracts revealed a protective effect from the oxidative stress agent $\left(\mathrm{H}_{2} \mathrm{O}_{2}\right)$. Similarly, all extracts inhibited the proliferation of the human colon adenocarcinoma cells (Caco-2) without cytotoxicity towards fibroblast cells (3T3). Although harvest season influenced the functional potential of Araçá fruit, genotype had the strongest influence.
\end{abstract}

Received Date: April 04, 2016
Accepted Date: June 30, 2016
Published Date: July 05, 2016

Citation: Rombaldi, C.V., et al. Influence of Genotype and Harvest Season on the Phytochemical Composition of Araçá (Psidium Cattleianum Sabine) Fruit. (2016) Int J Food Nutr Sci 3(2): 292-298.

DOI: $10.15436 / 2377-0619.16 .861$

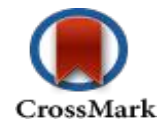

Keywords: Phytochemicals; Antioxidant capacity; Antiproliferative activity; Genotypes

\section{Introduction}

The majority of studies regarding human nutrition and health demonstrate that the occurrence of chronic degenerative diseases is negatively correlated to the dietary intake of grains, fruits, and vegetables ${ }^{[1-6]}$. Research data are corroborated by adhoc studies, which relate cause and effect in heterologous models (in vitro and in vivo chemical simulations) and by cohort studies ${ }^{[6-11]}$. On the other hand, although less common, there are studies that show the absence of such a correlation ${ }^{[12]}$.

Health benefits which are attributed to food rich in phenolics compounds and natural antioxidants have increasingly enhanced the search for new species that comprise relevant biological activities, such as protection against diseases. In this regard, Brazil has the advantage of having the planet's largest biodiversity and variability. However, many fruit species are still either unknown or underutilized in some cases due to difficulties in cultivation. The greatest richness in native Brazilian fruit species may be found in the Amazon region or in the savannahs. However, there are many fruit species in temperate climates with high potentialities ${ }^{[9,13-17]}$. Araçá (Psidium cattleianum Sabine) fruit, belonging to the Myrtaceae family, produces small sized yellowish or reddish fruits with attractive taste and aroma ${ }^{[9]}$. Although there are a few studies on the Araçá physicochemical composition, and its antioxidant and antimicrobial properties and on the development of products from its fruit ${ }^{[18-20]}$, the characterization of its phytochemicals in suc-

Copyrights: (C) 2016 Rombaldi, C.V. This is an Open access article distributed under the terms of Creative Commons Attribution 4.0 International License. 
cessive harvest seasons has never been investigated. This is a hotly debated issue that must be resolved since variations in the fruit composition due to the harvest season are well known ${ }^{[1,21,22]}$.

This study investigated the changes in the phytochemical content in six Araçá genotypes in six consecutive harvest seasons from 2008 through 2013, its antioxidant capacity and its antiproliferative activity against tumor cells.

\section{Materials and Methods}

\section{Plant material}

Red (AR9, AR19, and AR29) and yellow (AR27, AR46, and AR72) Araçá fruit (P. cattleianum Sabine) were harvested from the Embrapa Clima Temperado germplasm bank, Pelotas, RS, Brazil. One kilogram of fruit from each plant (three plants from each genotype) was collected when ripe ( $>50 \%$ fruit surface red or yellow in color, accordingly) during the harvest seasons of 2008 , $2009,2010,2011,2012$, and 2013 . Fruit were frozen in liquid nitrogen and stored at $-80^{\circ} \mathrm{C}$ until further analysis. All analyses were performed in triplicate.

\section{Physicochemical composition}

Soluble solids content and pH: Soluble solids content (SSC) was determined using a refractometer directly on the juice squeezed from the fruit flesh. Results were expressed in ${ }^{\circ} \mathrm{Brix}$. $\mathrm{pH}$ was measured directly on the fruit juice using a digital $\mathrm{pH}$-meter.

L-ascorbic acid content: L-ascorbic acid content was determined by high performance liquid chromatography (HPLC) using a reverse phase column CLC-ODS ( $4.6 \mathrm{~mm} \times 150 \mathrm{~mm} \times 5 \mu \mathrm{m})$, with a UV detector set at $254 \mathrm{~nm}^{[9]}$. Mean recovery index (RI) was $92.25 \%$ and results were expressed in milligrams of L-ascorbic acid per $100 \mathrm{~g}$ of fresh fruit.

Total anthocyanin content: Total anthocyanin content was determined spectrophotometrically, following the method described by $^{[23]}$. One $\mathrm{g}$ of ground fruit were extracted with $25 \mathrm{~mL}$ acidified ethanol ( $\mathrm{HCl}, \mathrm{pH} \mathrm{1.0)}$ and the solution kept at rest for $1 \mathrm{~h}$, in the dark, and homogenized every $5 \mathrm{~min}$. The mixture was then filtered and the volume completed to $50 \mathrm{~mL}$ with acidified ethanol. Absorbance was measured on a spectrophotometer (UV/Vis Ultrospec 2000 Pharmacia Biotech) at $520 \mathrm{~nm}$. Results were expressed in milligrams of cyanidin-3-glucoside per $100 \mathrm{~g}$ of fresh fruit.

Total carotenoid content: Total carotenoid content was determined spectrophotometrically, following the method described by ${ }^{[24]}$. Five grams of fruit were ground with celite, to which were added $20 \mathrm{~mL}$ of cold acetone $\left(4^{\circ} \mathrm{C}\right)$ for the extraction of pigments and homogenized for approximately $10 \mathrm{~min}$. The sample was vacuum-filtered and the residue was extracted two more times. The filtrate was transferred to a separatory funnel and hexane and distilled water were added. The lower phase was discarded and then washed with distilled water until the total removal of acetone. Absorbance of the hexane extract was measured in a spectrophotometer (UV/ Vis Ultrospec 2000 Pharmacia Biotech) at $450 \mathrm{~nm}$. Results were expressed in microgram of $\beta$-carotene per gram of fresh fruit.

Total tannin content: Total tannin content was determined spectrophotometrically, according to method described by ${ }^{[25]}$. Five $g$ of the sample were extracted with methanol $(10 \mathrm{~mL})$ under stirring for $1 \mathrm{~h}$ at room temperature. The extract was filtered and $100 \mu \mathrm{L}$ were reacted with the Folin-Denis reagent for 3 minutes when a saturated sodium carbonate solution was added. The solution was kept in the dark at room temperature for $1 \mathrm{~h}$. Absorbance was measured in a spectrophotometer (UV/Vis Ultrospec 2000 Pharmacia Biotech) at $760 \mathrm{~nm}$. Results were expressed in milligrams per $100 \mathrm{~g}$ of fresh fruit.

Total phenolic content: Total phenolic content was determined by spectrophotometry using the Folin-Ciocalteau reagent $\mathrm{t}^{[9]}$. Absorbance was measured in a spectrophotometer (UV/V is Ultrospec 2000 Pharmacia Biotech) at $760 \mathrm{~nm}$ wavelength. Results were expressed in milligrams of gallic acid equivalent (GAE) per $100 \mathrm{~g}$ of fresh fruit.

\section{Individual phenolic compounds contents}

Individual phenolic compounds contents were determined by high performance liquid chromatography (HPLC, Shimadzu) ${ }^{[9]}$. The phenolic compounds were extracted and hydrolyzed with $35 \mathrm{~mL}$ acidified methanol ( $\mathrm{HCl}, 15 \% \mathrm{v} / \mathrm{v})$. The extract was homogenized at $35^{\circ} \mathrm{C}$, in the dark, for $24 \mathrm{~h}$, filtered through cotton wool and the supernatant concentrated in a rotary evaporator at $40^{\circ} \mathrm{C}$ for 20 minutes. The concentrated residue was re-dissolved in methanol $(10 \mathrm{~mL})$ and centrifuged at $7000 \mathrm{xg}$ for $10 \mathrm{~min}$. A $30 \mu \mathrm{L}$ aliquot from the supernatant was injected in the HPLC-UV with the detector set at $280 \mathrm{~nm}$, reverse phase column CLC-ODS (4.6 mm x 150 $\mathrm{mm} \times 5 \mu \mathrm{m})$ and CLC-GODS guard column (4 $\mathrm{mm}$ x $200 \mathrm{~mm}$ x $5 \mu \mathrm{m}$ ). The mobile phase elution gradient with a solution of acetic acid in water (99:1) (solvent A) and methanol (solvent B), at a flow of $0.9 \mathrm{~mL} \cdot \mathrm{min}^{-1}$, starting with $100 \%$ of A, linearly changing to $60 \%$ of $\mathrm{A}$ and $40 \% \mathrm{~B}$, in $25 \mathrm{~min}$. The proportion was maintained constant for 2 minutes and then linearly changed to $95 \%$ of $\mathrm{A}$ and $5 \%$ of $\mathrm{B}$, at 37 minutes, and maintained constant for a further 5 minutes. Total run time was 45 minutes. Individual phenolic compounds were identified by comparing retention time and quantified by external calibration curve using the following standards of gallic acid (IR 87.56\%), p-coumaric acid (IR 92.34\%), ferulic acid (IR 103.87\%), quercetin (IR 93.25\%) and (-)-epicatechin (IR $90.08 \%$ ). Results were expressed in milligrams of the respective phenolic compound per 100 grams of fresh fruit. 


\section{In vivo antioxidant capacity}

Antioxidant capacity was determined using the in vivo system of eukaryotic Sacchoromyces XV 185-14C yeasts cell assay ${ }^{[26]}$. The yeast strain was inoculated in yeast peptone dextrose (YPD) solid medium with $1 \%(\mathrm{~m} / \mathrm{v})$ yeast extract, $2 \%(\mathrm{~m} / \mathrm{v})$ peptone, $2 \%(\mathrm{~m} / \mathrm{v})$ glucose and $2 \%(\mathrm{~m} / \mathrm{v})$ agar. Cells were transferred to a liquid medium (with the same composition of solid media without agar) and placed in an orbital stirrer at $28^{\circ} \mathrm{C}$ and at $160 \mathrm{rpm}$. Cell suspensions with $2 \times 10^{6} \mathrm{CFU} \mathrm{mL}^{-1}$ were treated with fruit extracts diluted in water at $1: 4$ (extract:water) and incubated for $1 \mathrm{~h}$ at $28^{\circ} \mathrm{C}$ while stirring in the dark. Cells were centrifuged at 2000 $\mathrm{x} \mathrm{g}, 28^{\circ} \mathrm{C}$ for $5 \mathrm{~min}$ and washed twice with $0.9 \%(\mathrm{~m} / \mathrm{v})$ sodium chloride solution. Cells were then treated with a solution of hydrogen peroxide $(50 \mathrm{mM})$, for $1 \mathrm{~h}$, at $28^{\circ} \mathrm{C}$. Samples were diluted in a solution of sodium chloride $(0.9 \% \mathrm{~m} / \mathrm{v})$, seeded in a complete YPD medium and incubated at $28^{\circ} \mathrm{C}$ for $48 \mathrm{~h}$. After incubation, the colonies were counted and survival percentages determined. Test plates were taken as reference, in which the total number of colonies in the control plate (without treatment) was considered as $100 \%$ cell survival.

\section{Antiproliferative activity against tumoral cells}

The antiproliferative effect of fruit extracts was tested in human colon adenocarcinoma cells (Caco-2), whereas a strain of rat's embryo fibroblasts (3T3) was used as control. RPMI 1640 medium, with bovine fetal serum (20\% v/v) and antibiotics (100 $\mathrm{UmL}^{-1}$ penicillin $\mathrm{G}, 100 \mu \mathrm{gmL}^{-1}$ streptomycin) was used for cell culture $\left(5 \times 10^{5} \mathrm{mLcells}^{-1}\right)$. Cells were placed in 96-well micro culture plates, with $100 \mu \mathrm{L}$ per well, for $24 \mathrm{~h}$, at $37^{\circ} \mathrm{C}$ in an atmosphere with $95 \% \mathrm{O}_{2}, 5 \% \mathrm{CO}_{2}$ and $100 \%$ relative humidity. After incubation, medium was removed from each well, with cells kept in the lower section. Cells were exposed to a new medium with $80 \mu \mathrm{gmL}^{-1}$ extract. After 48 -h incubation, cells were fixed by adding trichloroacetic acid $(50 \% \mathrm{~m} / \mathrm{v})$ at $4^{\circ} \mathrm{C}$ for $1 \mathrm{~h}$. The colorimetric assay was performed by adding a solution of sulforhodamine $\mathrm{B}(0.4 \% \mathrm{~m} / \mathrm{v})$ in acidified water (acetic acid $1 \% \mathrm{v} / \mathrm{v}$ ) in each well. After $30 \mathrm{~min}$ at room temperature, the non-fixed solution was removed by washing with acidified water. Stain fixed to cell proteins was re-solubilized with Tris $10 \mathrm{mM}(\mathrm{pH} 10.0)$ buffer, on an orbital stirrer at $50 \mathrm{rpm}$, at room temperature, for $5 \mathrm{~min}$. Optical density was read by ELISA plate spectrophotometric reader at $540 \mathrm{~nm}$. Absorbance data were correlated with a standard curve of viable cells and results were given in cell survival percentage compared to control treatment with cells cultivated in RPMI 1640 medium.

\section{Experimental design and statistical analysis}

This study was a descriptive analysis of 6 genotypes ( 3 plants per genotype) during 6 harvest seasons $(2008,2009,2010$, 2011, 2012, and 2013), with three fruit harvests per plant in each year. Analytical replicates were performed in triplicate. Results were evaluated by ANOVA and averages compared by Tukey's test at 5\% probability using Statistica v.7.1 (Statsoft, 2005).

\section{Results and Discussion}

\section{Effect of genotype and harvest season on the phytochemical composition of Araçá fruit}

The factor genotype affected all the evaluated dependent variables (soluble solids, $\mathrm{pH}, \mathrm{L}$-ascorbic acid, anthocyanin, carotenoid, tannin, and phenolic contents) within the set of independent variables (6 genotypes and 6 harvest seasons) under analysis (Table 1). Three of these genotypes produce red fruits (AR9, AR19, and AR29) and 3 produce yellow ones (AR27, AR46, and AR72). In general, both groups differed in $\mathrm{pH}$, anthocyanin, and total phenolic content.

Table 1: Influence of genotypes and harvests on the rates of L-ascorbic acid, total anthocyanins, total carotenoids, total tannins and total phenolics compounds of Araçá fruits

\begin{tabular}{|l|c|c|c|c|c|}
\hline & L-ascorbic acid & Total anthocyanins & Total carotenoids & Total tannins & Total phenolics compounds \\
\hline Genotype & $* *$ & $* *$ & $* *$ & $* *$ & $* *$ \\
Harvest season & $*$ & $*$ & $*$ & ns & $* *$ \\
\hline
\end{tabular}

ns - not significant

* Significantly different only after some years

** Significantly different

Soluble solids content and $\mathrm{pH}$ varied only among genotypes and not with harvest season (Table 2). AR72 with $7.17^{\circ}$ Brix had the lowest soluble solids content and AR19 with $11.91^{\circ}$ Brix the highest. AR29 fruit had the lowest $\mathrm{pH}(3.08)$ while AR46 had the highest (3.88). These results characterize Araçá as a fruit with relatively low SS and pH. 
Table 2: Soluble solids (SS) and pH of red (AR9, AR19, and AR29) and yellow (AR 27, AR46, and AR72) Araçá (mean rates correspond to $2008-2013$ harvests seasons)

\begin{tabular}{|l|c|c|}
\hline Genotype & $\mathbf{S S}^{*}(\mathbf{n}=\mathbf{6})$ & $\mathbf{p H}(\mathbf{n}=\mathbf{6})$ \\
\hline AR 9 & $10.04 \pm 0.56^{\mathrm{b}}$ & $3.19 \pm 0.03^{\mathrm{d}}$ \\
AR 19 & $11.91 \pm 0.66^{\mathrm{a}}$ & $3.34 \pm 0.02^{\mathrm{c}}$ \\
AR 29 & $10.67 \pm 0.99^{\mathrm{ab}}$ & $3.08 \pm 0.04^{\mathrm{e}}$ \\
AR 27 & $10.78 \pm 1.01^{\mathrm{ab}}$ & $3.72 \pm 0.02^{\mathrm{b}}$ \\
AR 46 & $11.73 \pm 1.16^{\mathrm{a}}$ & $3.88 \pm 0.07^{\mathrm{a}}$ \\
AR 72 & $7.17 \pm 0.75^{\mathrm{c}}$ & $3.83 \pm 0.05^{\mathrm{a}}$ \\
\hline
\end{tabular}

Means followed by the same letter in the column are not significantly different by Tukey's test $(\mathrm{p}<0.05)$. *Soluble solids expressed as ${ }^{\circ}$ Brix
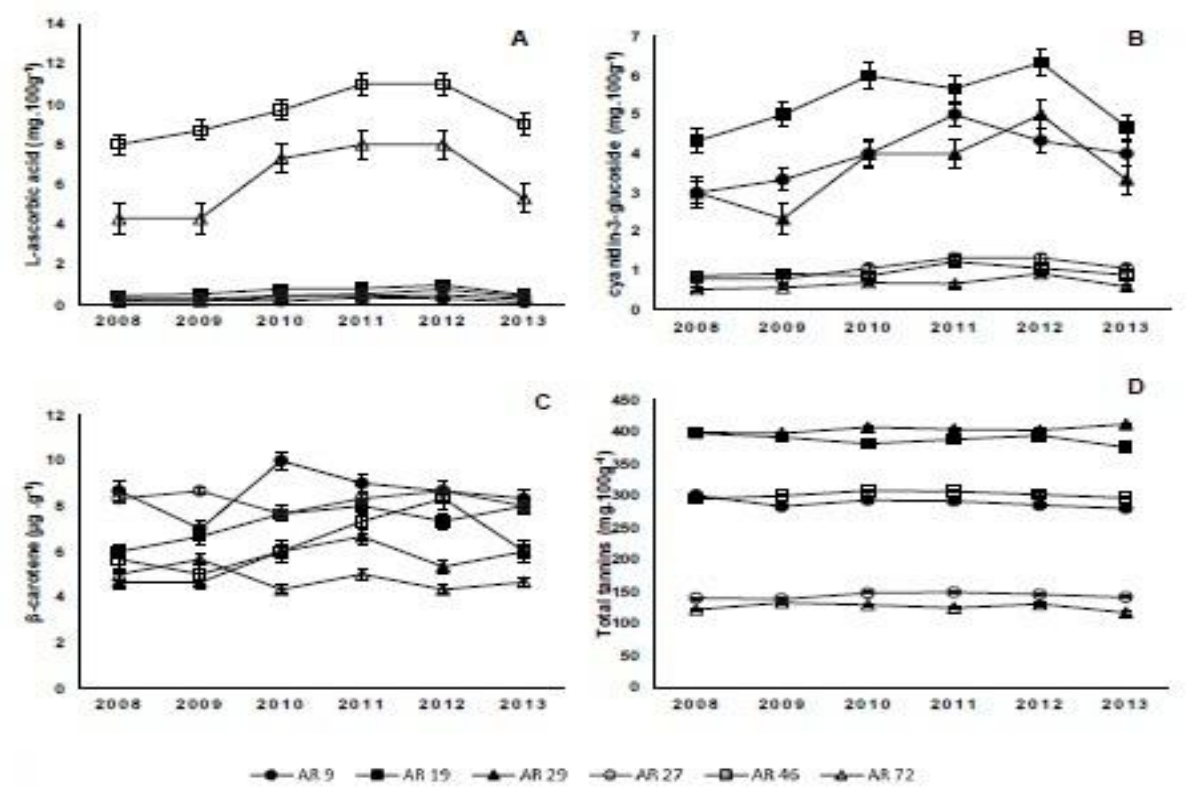

Figure 1: L-ascorbic acid (A), total anthocyanin (B), total carotenoid (C), and total tannin (D) content of red (AR9, AR19, and AR29) and yellow (AR27, AR46, and AR72) Araçá genotypes from six consecutive harvest seasons (2008, 2009, 2010, 2011, 2012, and 2013).

Genotype and harvest season influenced the L-ascorbic acid content in Araçá fruits (Figure 1A). Genotype AR46 was the

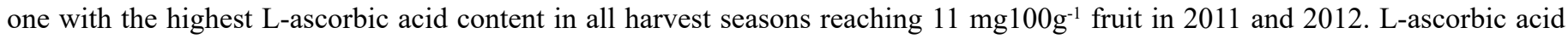

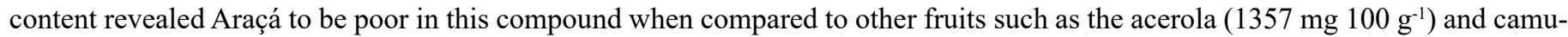
camu (1882 mg $\left.100 \mathrm{~g}^{-1}\right)$, native fruits to the Amazon biome ${ }^{[27]}$ or to other native species of southern Brazil, such as the guabiroba ${ }^{[28]}$ or butia ${ }^{[29]}$ with approximately 3050 and $9351 \mathrm{mg}$ of L-ascorbic acid per $100 \mathrm{~g}$ of fresh fruit, respectively ${ }^{[30]}$ revealing a wide variation for ascorbic acid content among genotypes and species. L-ascorbic acid content may also be affected by climate, such as solar radiation, temperature, and soil conditions ${ }^{[27,28,29,30]}$. The present study partially corroborated these findings since L-ascorbic acid content varied among genotypes and among harvest seasons.

There was a sharp difference in anthocyanin content between red and yellow fruits (Figure 1B). This fact was expected since these compounds are responsible for the red color of the fruit. Anthocyanin content was significantly higher in red genotypes in all harvests, with maximum of $6.33 \mathrm{mg}$ cyanidin-3-glucoside $100 \mathrm{~g}^{-1}$ fruit for the 2012 harvest for genotype AR19, whereas the lowest anthocyanin content was $1.33 \mathrm{mg}$ cyanidin-3-glucoside $100 \mathrm{~g}^{-1}$ fruit in yellow genotype AR27. Araçá anthocyanin content was relatively low when compared to fruit known for their high anthocyanin content, such as blackberry (47.7 mg cyanidin-3-glucoside $100 \mathrm{~g}^{-1}$ fruit), blueberry (128 mg cyanidin-3-glucoside $100 \mathrm{~g}^{-1}$ fruit) ${ }^{[31]}$ and strawberry $\left(23.4 \mathrm{mg} \text { cyanidin-3-glucoside } 100 \mathrm{~g}^{-1} \text { fruit }\right)^{[32]}$. Whereas anthocyanins are present throughout blackberry, blueberry, and strawberry fruit, these pigments occur only in the thin layer of fruit peel in Araçá.

Analysis of total carotenoid content in Araçá fruit showed that it was mainly influenced by genotype (Figure 1C). Only genotype AR46 was affected by the harvest season. Although Araçá genotypes had significantly different total carotenoid contents in each harvest they ranged from 4.33 to $10.0 \mu \mathrm{g} \beta$-carotene. $\mathrm{g}^{-1}$ (AR9), without a clear distinction between red and yellow fruits. A previous report also demonstrated carotenoid content to be higher in red fruits when compared to yellow ones ${ }^{[33]}$ higher carotenoid rates in red fruits when compared to those of yellow ones. Among the fruits analyzed by ${ }^{[29]}$, Araçá proved to have the highest carotenoid content, $6.270 \mu \mathrm{g} \beta$-carotene. $\mathrm{g}^{-1}$ fruit, significantly higher than the orange Brazilian cherry $\left(4.02 \mu \mathrm{g} \beta\right.$-carotene.g $\left.\mathrm{g}^{-1}\right)$ and butia (3.85 $\mu \mathrm{g} \beta$-carotene $\left.\mathrm{g}^{-1}\right)$ with orange-colored pulp. Data shown in this report confirm the literature, which reports that carotenoid 
content may be influenced by several factors, such as variety, plant tissue, ripening stage, harvest conditions, geographic location and others ${ }^{[34,35]}$.

Total tannin content was influenced only by genotype (Figure 1D). Red-colored fruits AR19 and AR29 had total tannin content significantly higher than those of the other genotypes, in each harvest, with maximum content reaching $398.5 \mathrm{mg}^{100 \mathrm{~g}^{-1}}$ fruit (2009) and $412.5 \mathrm{mg} 100 \mathrm{~g}^{-1}$ fruit (2013), respectively. There is no other report in the literature on tannin content of Araçá fruits. This group of phenolic compounds contributes towards the fruit's astringent characteristic and suggests that the taste of the red-colored fruits is sharper.

Araçá phenolic content varied significantly among genotypes, in the same harvest, with a clear difference between red and yellow fruits ranging from 414.7 to $689.67 \mathrm{mg} \mathrm{GAE} .100 \mathrm{~g}^{-1}$ (Figure 2A). Each year, red-colored genotypes had higher total phenolic content than the yellow ones, varying between 606.67 (AR9 in 2008) and 689.67 mg GAE.100g-1 fruit (AR29 in 2012). The same genotypes also provided the highest anthocyanin and total tannin content (over $283.5 \mathrm{mg} .100 \mathrm{~g}^{-1}$ fruit) when compared to yellow fruits. Phenolic content found for red (Psidium cattleianum) and yellow (Psidium cattleianum var. lucidum) Araçá reported by Biegelmeyer et al. (2011) was in the same range to that found in this study $\left(501.33 \mathrm{mg} \mathrm{GAE} 100 \mathrm{~g}^{-1}\right)$.
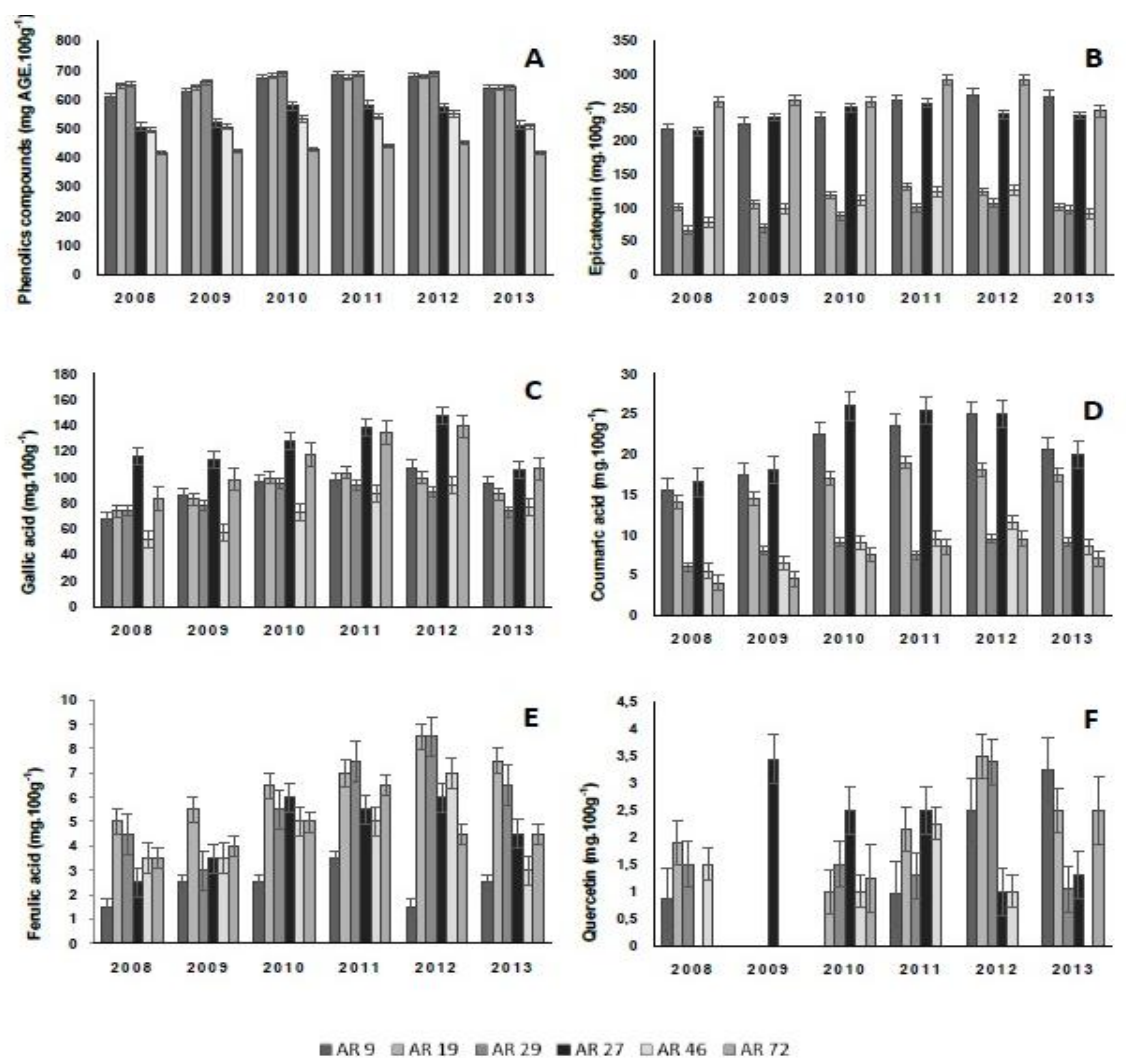

Figure 2: Total phenolic(A), (-)-epicatechin (B), gallic acid (C), p-coumaric acid (D), ferulic acid (E), and quercetin (F) content of red (AR9, AR19, and AR29) and yellow (AR27, AR46, and AR72) Araçá genotypes from six consecutive harvest season (2008, 2009, 2010, 2011, 2012, and 2013).

Among the individual phenolic compounds analyzed in the fruit (-)-epicatechin content ranging from 66 to $269 \mathrm{mg} .100 \mathrm{~g}^{-1}$ and gallic acid from 52 to $147 \mathrm{mg} 100 \mathrm{~g}^{-1}$ were the predominant phenolics (Figure 2). Variability existed in the composition and in the quantity of phenolic compounds among Araçá genotypes and harvest seasons ${ }^{[29]}$ investigated the profile of phenolic compounds of native fruits and identified molecules derived from gallic acid and quercetin as major components of the Araçá. However, they did not identify the specific phenolic compound measured.

\section{Effect of genotype and harvest season on the in vivo antioxidant capacity and the anti-proliferative activity of Araçá fruit extracts}

The extract's in vivo antioxidant capacity was evaluated by comparing survival levels of the yeast $S$. cereviseae against damages caused by the induction of oxidative stress by hydrogen peroxide (negative control) and Araçá extracts and this stress agent. Expectedly, yeast cells revealed sensitiveness to hydrogen peroxide and survival ranged between $42 \%$ and $43 \%$ in the presence of the oxidative agent. Results corroborated the $46 \%$ survival of yeasts treated with $\mathrm{H}_{2} \mathrm{O}_{2}$ reported by ${ }^{[11]}$. The protection ability of Araçá fruit extracts was observed when S. cereviseae cells were treated with Araçá fruit extracts and the oxidative stress agent. 
Harvest Season on the Phytochemical Composition of Araca Fruit

Table 3: Antioxidant capacity of red (AR9, AR19, and AR29) and yellow

(AR27, AR46, and AR72) araçá extracts towards S. cereviseae XV 185-14C

\begin{tabular}{|l|c|}
\hline Treatments & Survival (\%) \\
\hline Positive control (water) & $100.00^{\mathrm{a}}$ \\
Negative control $\left(\mathrm{H}_{2} \mathrm{O}_{2} 50 \mathrm{mM}\right)$ & $42.60^{\mathrm{d}}$ \\
AR9 $+\mathrm{H}_{2} \mathrm{O}_{2} 50 \mathrm{mM}$ & $85.83^{\mathrm{b}}$ \\
$\mathrm{AR} 19+\mathrm{H}_{2} \mathrm{O}_{2} 50 \mathrm{mM}$ & $86.00^{\mathrm{b}}$ \\
AR29 $+\mathrm{H}_{2} \mathrm{O}_{2} 50 \mathrm{mM}$ & $82.33^{\mathrm{bc}}$ \\
AR27 $+\mathrm{H}_{2} \mathrm{O}_{2} 50 \mathrm{mM}$ & $79.67^{\mathrm{c}}$ \\
AR46 $+\mathrm{H}_{2} \mathrm{O}_{2} 50 \mathrm{mM}$ & $80.83^{\mathrm{bc}}$ \\
AR72 $+\mathrm{H}_{2} \mathrm{O}_{2} 50 \mathrm{mM}$ & $81.50^{\mathrm{bc}}$ \\
\hline
\end{tabular}

Means followed by the same letter in the column are not significantly

different by Tukey's test $(\mathrm{p}<0.05)$.

The extracts' antioxidant capacity increased significantly the survival rates of yeast treated with $\mathrm{H}_{2} \mathrm{O}_{2}$. Red-color genotypes increased survival rate between 40 and $46 \%$ when compared to yeast cells exposed to $\mathrm{H}_{2} \mathrm{O}_{2}$. The same genotypes were found rich in anthocyanin, tannin, and total phenolic contents and thus corroborated reports by authors that assert the capacity of these molecules in protecting cells against damages caused by different oxidative stress agents ${ }^{[11,26,36]}$.

Since low cell death (between 2 and 9\%) occurred in control fibroblast cells (3T3), extracts revealed low cytotoxicity. Regardless of the harvest season, the inhibition of cell proliferation in all extracts was reported when the effect of extracts of Araçá fruits was evaluated for the proliferation of human colon adenocarcinoma cells (Caco-2). Tumoral Caco-2 cells treated with extracts of yellow-color genotypes had, in general, a higher survival rate (between 45 and 59\%) throughout the years (Table 4), that means these extracts have a lower antiproliferative activity when compared to red-color genotypes. The biochemical-molecular mechanism, by which extracts reduced the proliferation of $\mathrm{CaCo}-2$ cells without any cytotoxic activity with cells $3 \mathrm{~T} 3$, was not studied in current assay.

Table 4: Antiproliferative activity of red (AR9, AR19, and AR29) and yellow (AR27, AR46, and AR72) Araçá extracts tested against embryonic fibroblasts (3T3) and human colon adenocarcinoma (Caco-2) cells

\begin{tabular}{|c|c|c|}
\hline \multirow{2}{*}{ Genotype } & \multicolumn{2}{|c|}{ Survival (\%) } \\
\cline { 2 - 3 } & $\mathbf{3 T 3}$ & Caco-2 \\
\hline Control & $98.00^{\mathrm{a}}$ & $98.00^{\mathrm{a}}$ \\
AR9 & $96.50^{\mathrm{ab}}$ & $47.67^{\mathrm{b}}$ \\
AR19 & $95.67^{\mathrm{ab}}$ & $48.17^{\mathrm{b}}$ \\
AR29 & $93.50^{\mathrm{bc}}$ & $47.17^{\mathrm{b}}$ \\
AR27 & $95.00^{\mathrm{abc}}$ & $51.00^{\mathrm{b}}$ \\
AR46 & $92.33^{\mathrm{c}}$ & $49.67^{\mathrm{b}}$ \\
AR72 & $94.67^{\mathrm{bc}}$ & $48.83^{\mathrm{b}}$ \\
\hline
\end{tabular}

Means followed by the same letter in the column are not significantly different by Tukey's test $(\mathrm{p}<0.05)$.

\section{Conclusion}

Results showed that red and yellow Araçá genotypes have great phytochemical variability. Araçá fruit phytochemical content also varied with the harvest seasons, probably due to climatic variations. However the influence of genotype was stronger than harvest season on fruit phytochemical content and functional potential. Since fruit extracts increased the survival indexes of $S$. cereviseae cells, they revealed their protection capacity against oxidative stress agents. Araçá fruit extracts also inhibited the proliferation of human colon adenocarcinoma cells. Given these results these genotypes show potential to be commercially explored and the consumption of the fruit may be promote in face to the significant functional potential.

Acknowledgments: The authors would like to thank Fapergs and CNPq for providing financial support for research.

\section{References}

1. Boeing, H., Bechthold, A., Bub, A., et al. Critical review: vegetables and fruit in the prevention of chronic diseases. (2012) Eur J Nutr 51(6): 637-663.

2. Hartmann, T. Review from waste products to ecochemicals: Fifty years research of plant secondary metabolism. (2007) Phytochemistry 68 (2224): 2831-2846.

3. Oliveras-López, M.J., Berná, G., Jurado-Ruiz, E., et al. Consumption of extra-virgin olive oil rich in phenolic compounds has beneficial antioxidant effects in healthy human adults. (2014) Journal of Functional Foods 10: 475-484.

4. Poiroux-Gonord, F., Bidel L.P.R., Fanciullino A.L., et al. Health benefits of vitamins and secondary metabolites of fruits and vegetables and prospects to increase their concentrations by agronomic approaches. (2010)J Agric Food Chem 58(23): 12065-12082. 
5. Reiss, R., Johnston, J., Tucker, K., et al. Estimation of cancer risks and benefits associated with a potential increased consumption of fruits and vegetables. (2012) Food Chemical Toxicol 50(12): 4421-4427.

6. Tang, L., Lee, A.H., Su, D., et al. Fruit and vegetable consumption associated with reduced risk of epithelial ovarian cancer in southern Chinese women. (2014) Ginecologic Oncology 132(1): 241-247.

7. Dumitriu, D., Peinado, R.A., Peinado, J., et al. Grape pomace extract improves the in vitro and in vivo antioxidant properties of wines from sun light dried Pedro Ximénez grapes. (2015) Journal of Functional Foods 17: 380-387.

8. Hernandes, L.C., Aissa, A.F., Almeida, M.R. et al. In vivo assessment of the cytotoxic, genotoxic and antigenotoxic potential of maná-cubiu (Solanum sessiliflorum Dunal) fruit. (2014) Food Research International 62: 121-127.

9. Medina, A.L., Haas, L.I.R., Chaves, F.C., et al. Araçá (Psidium cattleianum Sabine) fruit extracts with antioxidant and antimicrobial activities and antiproliferative effect on human cancer cells. (2011) Food Chemistry 128: 916-922.

10. Neri-Numa, I.A., Carvalho-Silva, L.B.,Morales, J.P., et al. Evaluations of the antioxidant, proliferative and antimutagenic potential of araçá-boi fruit (Eugenia stipitata Mc Vaugh - Myrtaceae) of the Brazilian Amazon Forest. (2013) Food Research International 50(1): 70-76.

11. Stinco, C.M., Baroni, M.V., Naranjo, R.D.D., et al. Hydrophilic antioxidant compounds in orange juice from different fruit cultivars: Composition and antioxidant activity evaluated by chemical and cellular based (Saccharomyces cerevisiae) assays. (2015) Journal of Food Composition and Analysis 37: 1-10.

12. Boffetta, P., Couto, E., Wichmann, J., et al. Fruit and vegetable intake and overall cancer risk in the european prospective investigation into cancer and nutrition (EPIC). (2010) J Natl Cancer Inst 102(8): 529-537.

13. Beskow, G.T., Hoffmann, J.F., Teixeira, A. M., et al. Bioactive and yield potential of jelly palms (Butia odorata Barb. Rodr.). (2015) Food Chemistry 172: 699-704.

14. Franzon, R.C., Campos, L.Z.O., Porença, C.E.B.P., et al. Araçás do gênero Psidium: principais espécies, ocorrência, descrição e usos. (2009) Planaltina, DF, Brazil: Embrapa Cerrados.

15. Hoffmann, J.F., Barbieri, R.L., Rombaldi, C.V.et al. Butia spp. (Arecaceae): An overview. (2014) Scientia Horticulturae 179(2014): $122-131$.

16. Pereira, M.C., Hill, L.E., Zambiazi, R.C. et al. Nanoencapsulation of hydrophobic phytochemicals using poly (dl-lactide-co-glycolide) (PLGA) for antioxidant and antimicrobial delivery applications: Guabiroba fruit (Campomanesia xanthocarpa O. Berg) study. (2015) LWT - Food Science and Technology 63(1): 100-107.

17. Raseira, M.C.B., Antunes, L.E., Trevisan, R., et al. Espécies frutiferas nativas do Sul do Brasil. (2004) Pelotas, RS, Brazil: Embrapa Clima Temperado.

18. Caldeira, S.D. Hiane, P.A., Ramos, M.I.L., et al. Caracterização físico-química do araçá (Psidium guineense sw.) e do tarumã (Vitex cymosa bert.) do estado de Mato Grosso do Sul. (2004) Boletim do Centro de Pesquisa de Processamento de Alimentos 22(1).

19. Luximon-Ramma, A., Bahorun, T., Crozier, A. Antioxidant actions and phenolic and vitamin contents of common Mauritian exotic fruits. (2003)Journal of the Science of Food and Agricultural 83(5): 496-502.

20. Vriesmann, L.C., Petkowicz, C.L.O., Carneiro, P.I.B., et al. Acidic polysaccharides from Psidium cattleianum (Araçá). (2009) Brazilian Archives of Biology and Technology 52(2): 259-263.

21. Latocha, P., Jankowski, P., Radzanowska, J. Genotypic difference in postharvest characteristics of hardy kiwifruit (Actinidiaarguta and its hybrids), as a new commercial crop. Part I. Sensory profiling and physicochemical differences. (2011) Food Research International 44(7): 1936-1945. 22. Lima, V.L.A.G., Melo, E.A., Pinheiro, I.O., et al. Antioxidant capacity of anthocyanins from acerola genotypes. (2011) Ciencia e Tecnologia de Alimentos 31(1): 86-92.

23. Lees, D.H., Francis, F.J. Standardization of pigment analyses in Cranberries. (1972) HortScience 7: 83-84.

24. Rodriguez-Amaya, D. A guide to carotenoid analysis in foods. (2001)Washington: ILSI Press.

25. Gu, H., Li, C., Xu, Y., et al. Structural features and antioxidant activity of tannin from persimmon pulp.(2008) Food Research International 41(2): 208-217.

26. Soares, D.G., Andreazza, A.C., Salvador, M. Avaliação de compostos com atividade antioxidante em células da levedura Saccharomyces cerevisiae. (2005) Revista Brasileira de Ciências Farmacêuticas 41(1): 95-100.

27. Rufino, M.S.M., Alves, R.E., de Brito, E.S., et al. Bioactive compounds and antioxidant capacities of 18 non-traditional tropical fruits from Brazil. (2010) Food Chemistry 121(4): 996-1002.

28. Pereira, M.C., Steffens, R.S., Jablonski, A., et al. Characterization and antioxidant potential of brazilian fruits from the Myrtaceae family. (2012) J Agric Food Chem 60(12): 3061-3067.

29. Denardin, C.C., Hirsch, G.E., Rocha, R.F., et al. Antioxidant capacity and bioactive compounds of four Brazilian native fruits. (2015) Journal of Food and Drug Analysis 23(3): 387-398.

30. Lee, S.K., Kader, A.A. Preharvest and postharvest factors influencing vitamin C content of horticultural crops. (2000) Postharvest Biology and Technology 20(3): 207-220.

31. Jacques, A.C., Pertuzatti, P.B., Barcia, M.T., et al. Nota científica: compostos bioativos em pequenas frutas cultivadas na região sul do Estado do Rio Grande do Sul. (2009) Brazilian Journal of Food Technology 12(2): 123-127.

32. Severo, J., Tiecher, A., Chaves, F.C., et al. Gene transcript accumulation associated with physiological and chemical changes during developmental stages of strawberry cv. Camarosa. (2011) Food Chemistry 126(3): 995-1000.

33. Fetter, M.R., Vizzotto, M., Corbelini, D. D., et al. Propriedades funcionais de araçá-amarelo, araçá-vermelho (Psidium cattleianum Sabine) e araçá-pera (P. acutangulum D. C.) cultivados em Pelotas/RS. (2010) Brazilian Journal of Food Technology, III SSA: 92-95.

34. Gobbo-Neto, L., Lopes, N. P. Plantas medicinais: fatores de influência no conteúdo de metabólitos secundários.(2007) Química Nova 30(2): 374-381.

35. Tavarini, S., Degl'innocenti, E., Remorini, D., et al. Antioxidant capacity, ascorbic acid, total phenols and carotenoids changes during harvest and after storage of Hayward kiwifruit. (2008) Food Chemistry 107(1): 282-288.

36. Dani, C., Bonatto, D., Salvador, M., et al. Antioxidant protection of resveratrol and catechin in Saccharomyces cereviseae. (2008) J Agric Food Chem 56(11): 4268-4272.

Online ISSN: 2377-0619

Journal Title: International Journal Food and Nutritional Science Journal Short Name: Int J Food Nutr Sci
Ommega Online Publishers

E-mail: foodscience@ommegaonline.org

Website: www.ommegaonline.org

Int J Food Nutr Sci

Volume 3: Issue 2 